\title{
ORDINARY PEOPLE AND THE GREAT TIME OF TROUBLES: HOMESTEAD OWNERSHIP IN VELIKY NOVGOROD AND YAROSLAVL IN 1606-1618
}

\author{
Vladimir A. Arakcheev \\ Russian State Archive of Ancient Acts, Moscow, Russian Federation
}

\begin{abstract}
There are a lot of scientific papers about Russian cities between $16^{\text {th }}$ and $17^{\text {th }}$ centuries, however the discussion is focused mainly on economic activities and duties of citizens. The article presents the results of the study of transfer deeds of homesteads in Novgorod and Yaroslavl during the Time of Troubles. The dependence between the social status of the owner of a house, the value of his homestead and the character of its development is not always obvious. It turned out that in spite of the disorganization of state administration during the civil war, there was no mass transition of taxable households to 'belomestsy' in the cities studied. One of the most important factors of the economic crisis of the early $17^{\text {th }}$ century was military and political violence, which resulted in mass death of men and deformation of the family sex and age structure.
\end{abstract}

Key words: Time of Troubles, city homestead, taxable household, property, historical demography, crisis.

Citation. Arakcheev V.A. Ordinary People and the Great Time of Troubles: Homestead Ownership in Veliky Novgorod and Yaroslavl in 1606-1618. Vestnik Volgogradskogo gosudarstvennogo universiteta. Seriya 4, Istoriya. Regionovedenie. Mezhdunarodnye otnosheniya [Science Journal of Volgograd State University. History. Area Studies. International Relations], 2019, vol. 24, no. 2, pp. 113-119. DOI: https://doi.org/10.15688/jvolsu4.2019.2.10

УДК 930.272

Дата поступления статьи: 25.09.2018

ББК $63.3(2) 4$ Дата принятия статьи: 16.03.2019

\section{МАЛЕНЬКИЕ ЛЮДИ И БОЛЬШАЯ СМУТА: ДВОРОВЛАДЕНИЕ В ВЕЛИКОМ НОВГОРОДЕ И ЯРОСЛАВЛЕ В 1606-1618 ГОДАХ}

\author{
Владимир Анатольевич Аракчеев \\ Российский государственный архив древних актов, г. Москва, Российская Федерация
}

\begin{abstract}
Аннотация. Многое написано о русском городе XVI-XVII вв., однако дискуссии главным образом сосредоточены на экономической деятельности и повинностях горожан. В статье представлены результаты исследования купчих на дворы в Новгороде и Ярославле в период Смуты. Зависимость между социальным статусом дворовладельца, стоимостью его двора и характером его застройки прослеживается далеко не всегда. Было выявлено, что, несмотря на дезорганизацию государственного управления в период гражданской войны, в изученных нами городах не наблюдалось массового перехода тяглых дворов в руки беломестцев. Одним из важнейших факторов экономического кризиса начала XVII в. представляется военно-полити군 ческе насилие, приводившее к массовой гибели мужчин и деформации половозрастной структуры семьи.

К Ключевые слова: Смутное время, городская усадьба, тяглый двор, недвижимость, историческая демография, кризис.

Цитирование. Аракчеев В. А. Маленькие люди и большая Смута: дворовладение в Великом Новгороде и Ярославле в 1606-1618 годах // Вестник Волгоградского государственного университета. Серия 4, История. Регионоведение. Международные отношения. - 2019. - Т. 24, № 2. - С. 113-119. - (На англ.) - DOI: https://

(2) doi.org/10.15688/jvolsu4.2019.2.10
\end{abstract}


Introduction. It is difficult to conduct research on the history of 'posad' population in Russian cities of the first half of the $17^{\text {th }}$ century because of extremely low level of sources preservation. The primary sources, such as Pistsovye and Perepisnye knigi, provide a description of Russian cities and townspeople. However, the deeds of sale of homesteads, which were kept in the archives of local government institutions, are mostly lost. A homestead was the main structural unit of urban and rural settlements, and the Russian term ' $d v o r$ ' had two complementary meanings in the $17^{\text {th }}$ century.

Its full potential for illuminating both the typology of buildings on urban roads and also the legal basis for real estate purchase and sale transactions has not been realized. To appreciate this we must turn to a detailed examination of the documents and places, people and institutions, which are described in their contents. Finally, the real estate transfer deeds allow us to study the character of ruin during the Civil War of the first half of the $17^{\text {th }}$ century using demography methods. In many ways, the years were difficult for the citizens of Novgorod and Yaroslavl, as well as for Russian citizens as a whole. The report proposes a methodology for examining merchants in urban households and provides preliminary answers to the questions above.

Methods and materials. The basis of the source database of our report is the bills of sale of yards, which consist of deeds in the original and contracts included into the chancery books in Veliky Novgorod in 1609-1616. 12 of such documents were originally the part of the state archive of Sweden in Stockholm, but now they are stored in the Archives of St. Petersburg Institute of History of the Russian Academy of
Sciences and were first published in the $19^{\text {th }}$ century [1, col. 385-397]. Later the Swedish explorer I. Nordlander published 137 documents in copies and originals, but a significant part of them are bills on benches, yard places without buildings and places of church ministers. The publishers of Zapisnaya kniga of Novgorod's merchants in the yards of 1590-1591 reasonably believe that the practice of record management in Novgorod in the late $16^{\text {th }}$ century was similar to the one during the Swedish occupation. To this complex, we added eight bills for yards in Yaroslavl, dating back to 1606-1618 and preserved in the 1638 case of the investigation of mortgages ${ }^{1}$, studied by E. Talman [13]. It can therefore be assumed that what we have today fairly represents what has been lost, and that what is in print represents what still remains in manuscript.

Analysis. At the first stage of the study, we will examine everyday life structures of the population of Russia: the typology of homestead buildings, their cost and correlation with the social status of the owner. The formulae of the document included a list of buildings in a homestead and often an indication of the household placefiscal status: "white", which is free from direct taxes, or "black", which is included in taxable cadasters. The consideration of these factors makes it possible not only to reconstruct the structure of a townsman's household. There is an opportunity to identify the mutual influence of such factors as the social status of the owner, the cost of the homestead and the nature of its development. The table 1 shows the distribution of households in Veliky Novgorod and Yaroslavl at their cost, and the results of the study make it possible to significantly modify the views that have developed in historiography.

The distribution of homesteads of Veliky Novgorod and Yaroslavl at cost

\begin{tabular}{|c|c|c|c|c|c|c|c|}
\hline \multirow{2}{*}{$\begin{array}{l}\text { Sale prices } \\
\text { of real estate }\end{array}$} & \multicolumn{3}{|c|}{ 'Belyy dvor' (homestead on untaxable land) } & \multicolumn{3}{|c|}{ 'Chernyy dvor' (homestead on taxable land) } & \multirow[t]{2}{*}{ Total } \\
\hline & $\begin{array}{c}\text { 'Izba } \\
\text { nazemnaya' } \\
\text { or 'izba } \\
\text { na podzavalye' } \\
+2-4 \text { buildings }\end{array}$ & $\begin{array}{c}\text { 'Gornitsa } \\
\text { na podyz- } \\
\text { bitse' + 3-5 } \\
\text { buildings }\end{array}$ & $\begin{array}{l}\text { Building } \\
\text { type isn't } \\
\text { specified }\end{array}$ & $\begin{array}{c}\text { 'Izba } \\
\text { nazemnaya' } \\
\text { or 'izba na } \\
\text { podzavalye' + } \\
\text { 2-4 buildings }\end{array}$ & $\begin{array}{c}\text { 'Gornitsa } \\
\text { na podyzbitse'+ } \\
\text { 3-5 buildings }\end{array}$ & $\begin{array}{l}\text { Building } \\
\text { type isn't } \\
\text { specified }\end{array}$ & \\
\hline Up to 4,5 rubles & 7 & 4 & 6 & 42 & 11 & 2 & 72 \\
\hline $5-16$ rubles & 6 & 9 & - & 6 & 13 & 2 & 36 \\
\hline 17 rublesand more & - & 9 & - & - & 5 & - & 14 \\
\hline Totalof real estates & 13 & 22 & 6 & 48 & 29 & 4 & 122 \\
\hline
\end{tabular}


Based on the studies of Zabelin and the memories of foreigners, Gromov made a sharp distinction between the homesteads of wealthy townspeople and peasant households, as well as poor urban households. Gromov believed that the presence of such buildings as 'gornitsa', 'povalusha' and 'seni' was a characteristic feature of rich estates; the researcher also believed that 'banya' was the property of a rich homestead. At the same time, he considered ' $i z b a$ ' and a minimum of buildings as the criteria for poor homesteads [2, p. 193-197]. It's impossible for me to agree on the data obtained during our research with such simplified conclusions. What is not clear to Nordlander is "the correspondence between the prices and the descriptions stated, for example, how many buildings are included in a particular homestead" [9, p. 61].

Transactions for the sale of homestead are divided into three categories, depending on the value of the household: up to 4,5 rubles, from 5 to 16 rubles and 17 rubles and more. There is definitely only one pattern: every third of all sold yards belonged to the taxpayer, were at the lowest price category and had ' $i z b a$ ' as a residential building. But it is not possible to speak about prosperity or wealth of the homestead seller and buyer on the basis of this graduation. Firstly, a significant number of 'belyy' and 'chernyy' households, including 'gornitsa', 'seni', 'mylnya', cost less than 4,5 rubles, that is, valued by owners and buyers at the lowest price category. The homestead in the Legoshche Street, which was sold by the priest of the St. Sophia Larion to serviceman Odintsov in March 1612, included in its composition the following buildings: "gornitsa s podkletom, da klet na podklete, da seni s podsenyem, da sennitsa, da na dvore zhitnitsa, da konyushnya, da mylnya". In accordance with the concept of Gromov, this homestead should be considered as a household of a rich citizen, which, in spite of historiographical ideas, was sold for only three rubles [9, p. 97].

And vice versa, there are 11 cases when a homestead with ' $i z b a$ ' was two or three times more expensive than a homestead with 'gornitsa'. In May 1612 a townsman, a 'sarafannik' by profession, sold his homehold on Konyukhov Street to two townsmen, a 'zheleznik' and a 'molodozhnik' by profesion. The composition of his household included "izba na podzavalye, klet na potklete, seni na podsenye, banya, pech $v$ ogorode is ogorodnoyu zemleyu is yablonnymi derevtsy is vishni" [9, p. 99]. Perhaps, it was the presence of the garden that raised the cost of the homestead to 11 rubles in this particular case, although these facts can also be interpreted as an exception that proves the rule.

It is more important, however, to identify two trends in real estate pricing in Novgorod and Yaroslavl. The first tendency is that the 'white' homesteads of clerics on average cost much more than similar households of 'tyaglye lyudi'. The cost of the homestead sold by a widow-priest to her nephew, who had already been ordained, but apparently only pretended to be a parish priest, was the highest for residential property 40 rubles. This amount included the cost of not only the homestead, but also the office of the parish priest: there is an indication in the transfer deeds of this category that money is paid to receive the blessing for the post occupation $[9$, p. 140].

The second tendency of pricing was to understate the value of the homestead due to the presence of a large number of empty households in Novgorod after 'nemetskiy pogrom'. On August 25, 1611, a deal was signed for transfering an empty taxable homestead 'iz otsynki' to townsman Matyushka-prasol by city elder. The recipient of the homestead paid 1,75 rubles to the city treasury in accordance with the document - 'otsynnym spiskom gratskikh starost'. Six months later, in March 1612, Matyushka-prasol sold his former homestead for the same amount to Novgorod clerk Lystsov, who was in charge of registering real estate transactions [9, p. 94-95]. The corruption component of these transactions, apparently, consisted in understating household costs to mutual benefit of both parties of transactions.

Therefore, the homestead cost was determined by a number of factors, which could include the location of a household, the dilapidated state of outbuildings, the presence of another homestead in seller's possession, etc. The conclusion above is correlated with the results of Mazur's study, who found that there was no dependence of a homestead area on prosperity of its owner in the cities of the center of Russia [8, p. 156].

Now we turn to the second problem: the legal basis for real estate purchase and sale 
transaction. In historiography the understanding of a wave-like character of government policy towards 'posad' was formed, even from the time of Smirnov's classic work publication. It is believed that the periods of 'posadskoye stroenie' of the 1550 s and early 1600 s were followed by periods of reaction and the growth of 'belye slobody'. The facts quoted by Smirnov confirmed the contrary: according to the documents cited by him, the 'posadskie lyudi' sold their households primarily to representatives of their own strata. The period of the expansion of 'belomestsy' in Kostroma and Nizhny Novgorod 'posady' covered the time after the compilation of the books 'valovoe pismo' in the 1620s [12, p. 178, 266].

The data for $1600-1630$ years in Yaroslavl represent that in the 1638 case, there were 65 original bills for homesteads and benches, and many of these contracts formalized the transition of households from 'posadskie lyudi' to 'belomestsy', but only one is dated by the "Time of Troubles". This charter, dated January 20, 1618, was saling the homestead of the sovereign's 'barash' Chrysanthey Ivanov, which was bought by prince Bolkhovsky ${ }^{2}$. Since 'barash', like other sovereign's artisans, lived in a tax-free place, we have the right to assume that the social character of the household in this case has not changed. In total, only two out of 114 Novgorod's and Yaroslavl's acts for 1606-1618, relating to Veliky Novgorod, registered the deals for saling homesteads of taxable people to 'belomestsy'. There are doubtful cases among the other 120 acts, since the status of a homestead is not indicated in dozens of merchants, but in such cases I tend to explain the legal nature of the transaction by the social status of the owner.

In March 1612 the Novgorod's 'posadskiy chelovek' Matushka sold a half of his homestead to the clerk Ondrey Lystsov, who was one of the two compilers of the 'zapisnaya kniga' of 16111616. Above we have assumed that this transaction was corruptive, but in this case it is important that the taxable homestead passes into the hands of 'belomestetsy', and apparently changes its status. The second case refers to March 6, 1613, when Novgorod's 'posadskiy chelovek' Bogdan 'khlebnik' sold his homestead to the metropolitan peasant Tomil, a hat-worker by profession. It is unknown from the deed, whether the homestead kept its status or changed it, turning into tax-free. In some deeds the status of a homestead is defined as existing originally: a homestead sold by a gunner's widow to another gunner in Novgorod was identified in the deed as 'istari pushkarskoy' [9, p. 153].

If it was a high proportion of transactions, in accordance with which 'white' homesteads were passed to 'white' people, and taxed ones to 'black' people, we can assume the existence of a defined and controlled order. In order to understand who exercised control over transactions, let's compare 'zapisnye knigi kupchikh' to homesteads in Novgorod in 15901591 and 1611-1616. In the early book all 115 deeds were issued for transactions between people of equal status and did not change the character of the household ownership [4, p. 118172]. It could be assumed that in 1590-1591 the control over real estate sale transactions was carried out by 'prikazy' or a governor, but in 1611 the highest control authority in Novgorod was the Swedish occupation administration headed by Jakob De la Gardie.

The officials who were supposed to exercise such a control are mentioned twice in 'zapisnye knigi'. In 1591 'gorodovye prikazchiki' "otveli mitropolichyu krestianinu Manukhe Stepanovu na sofeiskoy zemli v Chudintsove ulitse" (gave) the deserted homestead [4, p. 155]. In 1612, 'Novgorodskie starosty' sold him 'iz otsynki pustoy tyagloy dvor'; for it he 'po otsynnomu spisku gradskikh starost dal v gradskuyu kaznu 2 rublya bez cheti' [9, p. 94]. In the hands of these local authorities documents should have been placed on the basis of which the city clerks sanctioned the conclusion of the transaction of homestead buying and selling.

The problem of the residence of 'white' people in 'posady' goes back to the Sudebnik of 1550 and the Zemstvo Charter Acts of 1552-1556. According to Clause 91 of the Sudebnik, citizens who were engaged in trade were prohibited to live in urban homesteads belonging to monasteries [10, p. 259]. 'Razmetnye knigi' and other similar documents mentioned in article 72 of the Sudebnik recorded the status of a homestead; they were used to compile 'pistsovye knigi' in course of descriptions, and produced Godunov's 'posadskoe stroenie' in the 1600s. Thus, by the 
beginning of the $17^{\text {th }}$ century the status of households was understood by local communities; this allowed the elders to sale homesteads of runaway townspeople. It was also clear to the administration, whose representatives, if necessary, asked permission not to pay taxes from taxable yards. In 1614, Vasily Korin was appointed to the post of clerk in Pskov, where he bought 'dvorovoe tyagloe mestechko okladom $v$ tyagle z dvu deneg'. In response to the petition of Korin sovereign ordered voivode not to take taxes from his homestead 'do tekh mest, poka mesta on Vasiley u nashego dela vo Pskove budet' ${ }^{3}$. Only in the 1620s 'belomestsy' began to massively buy the taxable households of the townspeople, which in turn caused a reciprocal response from the state in the form of 'posadskie stroeniya'.

We turn to formulating the third problem, the approaches to the study which allows us to outline the complex of the sources analyzed in the research. This is the problem of the economic state of a Russian city during the Time of Troubles. What was it: a crisis or "ruin"? The remaining sources contain conflicting data. On the one hand, cities with their fortifications were to attract neighboring peasants and thereby replenish the decline of townspeople population. Thus, in the midst of the Time of Troubles in 1609-1610 11 peasants went to the city of Kaluga with their wives, children and property from estate nobleman Iznoskov and, as follows from his petition, lived there at least up to $1613^{4}$.

On the other hand, only modeling the economic state of the city during the time of Troubles can provide an answer to such a difficult question. One of the most important tasks in solving historical and sociological problems is searching and defining criteria in the process of creating a model. A significant part of the homesteads and shops in Novgorod was sold because of excessive taxes: the sellers complained that they were selling homesteads "because of poverty and taxes" [9, p. 112]. At the first stage of the study we determine the proportion of households sold due to inability of their owners to play taxes and perform services. In Veliky Novgorod only 9 households were registered, the owners of which explained the need to sell the homestead because of inability to pay taxes (only $11 \%$ of the total number of sold homesteads). But it is quite obvious that officials did not always state reasons for selling real estate.

We see the possibility of modeling the economic situation of the urban population on a gender basis. There was a significant proportion of widows among the sellers of real estate, who in some cases unequivocally characterized their miserable situation, as widow Stepanidka did, who "skazala, chto prodala ona dvor svoy Timokhe potomu, chto u nee detey ne ostalosya i tyagla tiyanuti nevozmozhno" [9, p. 72]. But widowhood heavily responded to the situation of families living in tax-free homesteads. How many households were sold by widows due to inability to pay taxes and conduct the household due to the loss of a head of the household? The taxable 'black' homesteads were sold by widows in 29 cases, accounting for $35,8 \%$ of all 'black' households sold. The 'white' homesteads sold by widows (mainly widows of clergymen) accounted to $19,5 \%$ of all sold households in this category (8 items).

This facts allow us to formulate the problem of the economic crisis essence in Russian cities in the Time of Troubles and its causes. One of the first Russian historians who turned to his study, was Yanitskiy, who found out on the basis of 'pistsovye knigi' of the 1580 s that the crisis in Novgorod hit first of all commercial and industrial population $[15$, p. 100$]$. Bakhrushin tried to understand the dynamics of the crisis in Novgorod and pointed to the growth of taxes as the main cause of desolation in the $1580 \mathrm{~s}$; however, in Novgorod in the early $17^{\text {th }}$ century Bakhrushin had already seen the signs of economic recovery [3, p. 147, 150, 211]. A similar point of view was advocated by Pronshtein [11, p. 44-45].

The first Russian historian to consider the crisis of the late $16^{\text {th }}$ century through the prism of changes in the structure of the population was Kolycheva, who pointed out the fateful role of the epidemic of the $1550 \mathrm{~s}-1560 \mathrm{~s}$. "The epidemic changed the age and sex composition of the population, spawned a large number of incomplete and childless families, violated family and neighbor ties in villages and thus led to the deformation of the community. If an incomplete family was deprived of male labor and the help of neighbors, it was unable to plow the parcel in the same volume. Violating normal reproduction of the 
population (as a result of the epidemic mainly) led to the fact that the growth of the economic crisis became irreversible for the period [7, p. 187].

The explanatory model of Kolycheva is applicable not only to the agrarian crisis of the second half or the $16^{\text {th }}$ century, but also to the economic catastrophe of the Time of Troubles. More than a third of taxable Novgorod's households sold by widows is a sign of a significant deformation of the urban family demographic structure. The testimony of Stepanida widow about the death of her children ("ne ostalosya") points to the death of the heirs as an essential cause of impending poverty. It can be assumed that before the death of the heirs the widow sought means to maintain the former standard of living of the family: the average well-being homestead of four buildings valued at 8 rubles, is described in the deed $[9$, p. 72$]$. Consequently, it was the loss of population that predetermined the contours of the economic crisis during the Civil War, when, according to Braudel, "death is at the center of everyday life, like a church in the center of the village" [5, p. 157].

However, the dynamic growth of crisis phenomena was directly related to the military and political confrontation between regions and interventionists. This thesis is confirmed by the results of studying customs books of Veliky Novgorod for 1610-1614. In 1610-1611 Novgorod actively traded with large Russian cities - Vologda, Ostashkov, Torzhok, and its turnover exceeded 25 thousand rubles. In 1613-1614 its market shrinks to the regional size, and merchants from Ivangorod and peasants of Novgorod land prevail among the out-of-town traders. As shown by Varentsov, the number of appearance of out-oftown traders decreased 16,5 times, and the total turnover decreased 6 times during three years $[14$, p. 112-115].

Results. The results of the research once again confirmed the outstanding scientific significance of the documents of Stockholm Archives for studying Russian cities in the "Time of Troubles". For active civil war figures ordinary citizens were a community of conformists obediently following every new leader: "vsekh etikh kuptsov, pirozhnikov i sapozhnikov", as contemptuously referred to residents of Moscow Konrad Bussov [6, p. 151]. However, the elected elders of these conformists controlled the conclusion of transactions for real estate sale and prevented a change in the homestead fiscal status. It turned out that in spite of the disorganization of state administration during the civil war, there was no mass transition of taxable households to the hands of 'belomestsy' in the cities studied by us. An unprecedented complex of sources, characterizing the daily life of Veliky Novgorod, makes it possible to build a daily model and, after checking its parameters on the materials of other cities, to extrapolate the conclusions to the Russian cities of the first half of the $17^{\text {th }}$ century as a whole.

\section{NOTES}

${ }^{1}$ Russian State Archive of Ancient Acts. Fund 396. Reg. 1. Part 27. Doc. 41567.

2 Russian State Archive of Ancient Acts. Fund 396. Reg. 1. Part 27. Doc. 41567. List 234 235.

${ }^{3}$ Russian State Archive of Ancient Acts. Fund 141. Reg. 1. 1614 g. Doc. 2. L. 198-199.

${ }^{4}$ Russian State Archive of Ancient Acts. Fund 396. Reg. 1. Part 24. Doc. 37600. L. 1-3.

\section{REFERENCES}

1. Akty, otnosyashchiesya do yuridicheskogo byta drevney Rossii. V 3 t. T. 2. [Acts Relating to the Legal Life of Ancient Russia. In 3 vols. Vol. 2]. Saint Petersburg, Tipografiya imperatorskoy akademii nauk, 1864, no. 148, col. 386-411.

2. Artsikhovskiy A.V., ed. Ocherki russkoy kultury XVII veka. V 2 ch. Ch. 1 [Essays on the Russian Culture of the $17^{\text {th }} \mathrm{c}$. In 2 parts. Part 1]. Moscow, Izd-vo MGU, 1979. $352 \mathrm{p}$.

3. Bakhrushin S.V. Nauchnye trudy. V 4 t. T. 1 [Nauchnye Trudy. In 4 vols. Vol. 1]. Moscow, Izd-vo AN SSSR, 1952. $263 \mathrm{p}$.

4. Baranov K.V., ed. Velikiy Novgorod vo vtoroy polovine XVI v.: sb. dokumentov [Veliky Novgorod in the Second Half of the $16^{\text {th }} \mathrm{c}$. Collection of Documents]. Saint Petersburg, Dmitriy Bulanin Publ., 2001.274 p.

5. Brodel F. Chto takoe Frantsiya? $V 2 \mathrm{kn}$. Kn. 2. Lyudi i veshchi [What is France? In 2 books. Book 2. People and Things]. Moscow, Izd-vo im. Sabashnikovykh, 1995. 244 p.

6. Bussov K. Moskovskaya khronika. 15841613 [Moscow Chronicle of 1584-1613]. Moscow, Leningrad, Izd-vo AN SSSR, 1961. $335 \mathrm{p}$.

7. Kolycheva E.I. Agrarnyy stroy Rossii XVIv. [Agrarian System of Russia in the $\left.16^{\text {th }} \mathrm{c}.\right]$. Moscow, Nauka Publ., 1987. 228 p. 
8. Mazur L.D. Dvory posadskogo sosloviya na territorii goroda XVII v. [Households of Posad Estate in the Cities of the $17^{\text {th }} \mathrm{c}$.]. Shvidkovskiy D.O., ed. Issledovaniya po istorii arkhitektury i gradostroitelstva. Moscow, DPK-Press Publ., 2011, iss. 2, pp. 151-165.

9. Nordlander I., ed. Real Estate Transfer Deeds in Novgorod 1609-1616. Stockholm, Almqvist \& Wiksell International Publ., 1987. $171 \mathrm{p}$.

10. Pamyatniki russkogo prava [Documents on Russian Law]. Moscow, Yuridicheskaya literatura Publ., 1956, iss. 4. 632 p.

11. Pronshteyn A.P. Velikiy Novgorod v XVI veke [Veliky Novgorod in the $16^{\text {th }} \mathrm{c}$.]. Kharkiv, Izd-vo Kharkovskogo gosudarstvennogo universiteta, $1957.285 \mathrm{p}$.

12. Smirnov P.P. Posadskie lyudi i ikh klassovaya borba do serediny XVII v. V2 t. T. 1 [People of Posads and their Class Struggle until the Mid of the $17^{\text {th }}$ c. In 2 vols. Vol. 1]. Moscow, Leningrad, Izd-vo Akademii nauk SSSR, 1947. $490 \mathrm{p}$.

13. Talman E.M. Borba posada Yaroslavlya s svetskimi i dukhovnymi feodalami v pervoy polovine XVII v. [The Struggle of Yaroslavl Posad with Secular and Spiritual Feudal Lords in the Early $17^{\text {th }} \mathrm{c}$.]. Istoricheskie zapiski. Moscow, Izd-vo AN SSSR, 1946, vol. 20, pp. 96-126.

14. Varentsov V.A. Torgovlya i kupechestvo Novgoroda po dannym tamozhennykh knig [Trade and Merchants of Novgorod according to Customs Books]. Torgovlya i predprinimatelstvo $v$ feodalnoy Rossii [Trade and Entrepreneurship in Feudal Russia]. Moscow, Arkheograficheskiy tsentr Publ., 1994, pp. 93-116.

15. Yanitskiy N.F. Ekonomicheskiy krizis $v$ Novgorodskoy oblasti XVI veka [The Economic Crisis in the Novgorod Oblast of $16^{\text {th }} \mathrm{c}$.]. Kiev, Tipografiya Universiteta im. Sv. Vladimira, 1915. 151 p.

\section{Information about the Author}

Vladimir A. Arakcheev, Doctor of Sciences (History), Director, Russian State Archive of Ancient Acts, Bolshaya Pirogovskaya St., 17, 119435 Moscow, Russian Federation, arakk@rambler.ru, https:// orcid.org/0000-0002-8389-3806

\section{Информация об авторе}

Владимир Анатольевич Аракчеев, доктор исторических наук, директор, Российский государственный архив древних актов, ул. Большая Пироговская, 17, 119435 г. Москва, Российская Федерация, arakk@rambler.ru, https://orcid.org/0000-0002-8389-3806 